\title{
Research on the Innovation of MBA Talents' Training Mode -- Based on the Perspective of Double Helix Structure
}

\author{
Xin SU ${ }^{1, a}$, Hui ZHANG ${ }^{2, b}$, Peng-Zhi KONG ${ }^{3, c,{ }^{*}}$
}

\author{
1,2,3 Business Management Administration Shandong University of Finance and Economics \\ Jinan; 250002; P R China \\ Jessica880120@163.com \\ *Peng-Zhi KONG
}

Keywords: MBA, Talent Training Mode, Double Helix Structure.

\begin{abstract}
The key of talent cultivation is the innovation of talent training mode. "Cooperative" training model emphasizes the importance of postgraduate educational practice, so this paper constructs an operable three party collaborative training mode of the model of school-enterprise-government based on the double helix structure of DNA and the innovation and practice of MBA students' training experience in Shandong University of Finance and Economics, which can provide a reference for MBA students to effectively enhance their core competence.
\end{abstract}

\section{Introduction}

The key of training talent lies in the construction of personnel training mode, which has decisive effects on the quality of personnel training. In 2010, the China Ministry launched a reform in the country about comprehensive education of the professional degree graduates and proposed the establishment of Chinese characteristic education system of professional graduates, which needs to innovative talents' training mode and reform the management system.

The training goal of MBA is to develop a practical, complex, application-oriented and high-level management personnel who can be competent for the management of industrial and commercial enterprises and economic management departments. This paper constructs a practical and synergistic training mode of school, business and government combining with the reform and practice experience of MBA students' training of Shandong University of Finance and Economics to strengthen their competence of profession and skills. The synergistic training mode is of great practical significance to cultivate the professional competitiveness of MBA students, improve the quality of students' training, and cultivate the talents of business administration in line with the needs of China's social and economic development.

\section{A Literature Review}

It is generally accepted by the academic circles that the mode of synergistic training of graduate student is developed on the basis of "collaborative" graduates' education mode. Li Shengbing (1997) argues that "cooperative" education mode of postgraduates is a cooperation of university and enterprise; Yang Wei (2006) proposes firstly "synergistic innovation of graduates' education"[1] on the basis of the relationships between graduate students, instructors and training environment, which brings the transformation from "collaborative" training mode to synergistic mode. Huang Zhengfu, Yi Lian (2014) argues that "graduates' collaborative and innovation training mode" is a kind of concept, paradigm and method in the process of postgraduates' training, which needs different cultivating subjects breaking the institutional barriers of innovation, releasing the vitality of innovative elements and forming the concept of depth cooperation[2]. In addition, Du Dong (2014) proposes the "synergistic" training mode of graduates and regards the training of graduates as a collaborative system with organization, resource, information and process [3].

"Collaborative" training mode and "synergistic" training mode both emphasize the importance of graduates' educational practices, and the results of research are mainly reflected in the aspects of target, concept, process, management of the synergistic training graduates and how to promote the 
mode. Based on the perspective of "collaborative" training mode, Wang Quanlin (2005) believes that the goal of "collaborative" training mode aims to cultivate students of application and development abilities and the teaching, scientific research, production and development closely integrates in the process of cultivation[4]; Sun Chongwen (2005) thinks that the universities should promote institutional innovation in aspects of part-time tutor system, the rapid expansion of the scale of professional degree graduates and enterprises' participating in the postgraduates' training[5]. In addition, based on the perspective of "synergistic" training mode, Yang Wei (2006) regards that we should grasp the dual roles of three elements in graduates' education, such as graduates, tutors and graduates' training environment, and we also need to adhere to three concepts of harmony, stimulation and win-win in order to realize the synergistic innovation of graduates' education [6]. $\mathrm{Xu}$ Yaqing (2009) proposes that the cultivation of graduate students' innovative ability requires management, knowledge and skills and resource coordinating with each other in order to improve the overall quality of graduate students [7]. From a practical point of view, comparing with "collaborative" mode, the "synergistic" training mode is more comprehensive, systematic and institutionalized and its level is relatively higher. Therefore, to realize the transformation of the graduates' training mode, we need to build a cooperative training system for the diversified teachers and cultivate the synergistic innovation mechanism and path of the graduates in different subjects [2].

\section{The Realistic Reflection of MBA Talents' Training Mode}

China's MBA education began in 1990, although it has experienced the stages of learning from and imitating to the Western, digesting and absorbing, its training mode is still single, for example, most training institutions used to imitating the style of "knowledge + Harvard Case" teaching mode, so there exist many problems on the aspect of training effects ${ }^{[8]}$.

\section{The Gap between Training Objectives and Social Needs}

Due to the lack of evaluation system of training effect and MBA personnel cultivating mechanism, the goals of MBA training separate from the social needs causing the gap exists between MBA students and employers' psychological expectations and the gap is larger with enterprises' higher level of innovation.

\section{The Lack of Flexibility}

The MBA students in our country are mainly based on in-service students, and the training methods are lack of flexibility. In addition, the talents' training mode of most colleges and universities is too single mainly based on the theoretical knowledge and lacks practical ability training, teaching materials and social practice.

\section{The Strong Theory Ability and Weak Practical Ability of the Teachers}

The abilities of teachers determine the training quality of students, although MBA teachers' are with much theoretical knowledge and often participate in business consulting, decision making and other related work, they are also limited to theoretical guidance and cannot involve in the actual operation and management process of enterprises comprehensively and systematically.

\section{The Short of Applicability of Dissertation}

MBA dissertation should be beneficial to solve practical problems, however, some students due to the lack of practical experience and the difficult of designing topics resulting in low quality of their dissertation and cannot provide reasonable solutions to the current problems of enterprises.

Thus, it can be seen that although the university has theoretical advantages of professional education in the training of MBA talents, its practical ability is insufficient. Therefore, this paper discusses the synergistic training motivation mechanism of government, enterprises and schools strengthened by the double helix link and the teaching and management projects based on the double helix structure of professional ability and practice ability. 


\section{The Innovative Path of MBA Talents' Training Mode}

The "double helix" model of the core competence of MBA students' cultivation is a kind of interactive training mode, which is based on the plural link between the enterprise skilled education and the professional education. So we should improve the system construction between MBA training institutions, schools and enterprises, form interest driven mechanism of the enterprise and brand promotion mechanism of the professional education, and strengthen the dynamic coupling power of two kinds of chains named as enterprise skilled education and school professional education, just as shown in figure 1.

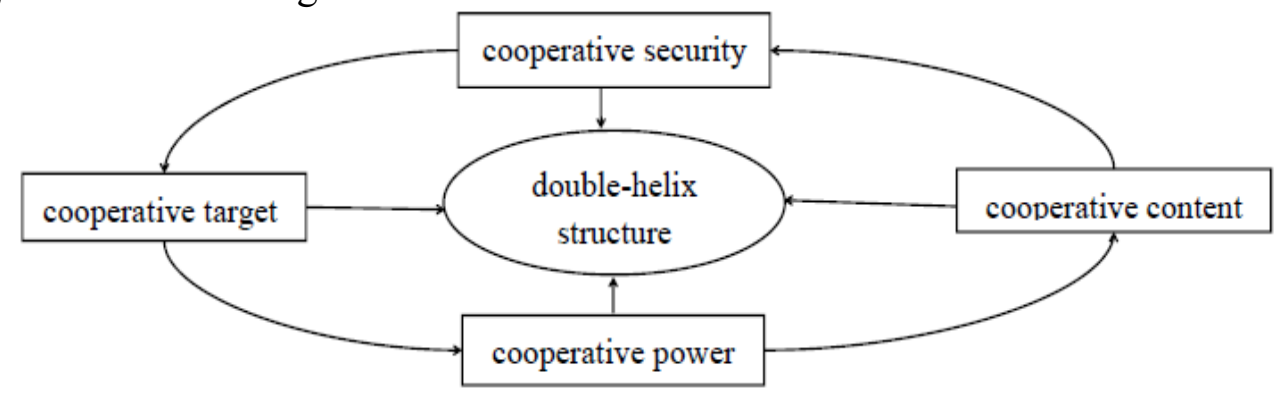

Figure.1 synergistic path of MBA talents' training

This paper determines the dynamic mechanism of spiral development through analyzing the synergistic benefits between the school, enterprise and government based on MBA personnel training objectives and double helix structure defined by social demands, builds MBA talents' training content and ultimately cultivates applied talents with knowledge integration ability and flexibility. The main contents include the following points:

\section{School and Enterprise Coordination}

\section{The Coordination of Training Project}

The school should combine the enterprise management personnel training with school curriculum development plan to improve the theoretical knowledge of the students and make them study more objectively.

\section{The Coordination of Course Teaching}

The professional competence of the students cultivated by school should combine with the professional ethics and ability of human communication well.

\section{The Coordination of Practice Base Construction}

Out-campus practice is mainly to train students' ability of adapting to future work. Enterprises can form solutions with the help of teachers and students' professional backgrounds.

\section{The Coordination of Dissertation}

In his paper, the author could introduce the guidance of enterprise tutor to strengthen the practical significance and economic benefits.

\section{School and School Coordination}

\section{The Coordination of Teachers' Resource Construction}

There are differences in each MBA training institute based on the advantages of school discipline, which can be further shared by teachers in professional courses.

\section{The Coordination of Case Construction}

The school should adopt the integrated teaching method to shorten the development cycle of the case and cultivate the students' ability of coping with the problems. 


\section{School and Government Coordination}

\section{The Coordination of Course Teaching}

The government's economic policies are introduced into the MBA curriculum module, which can promote the implementation of the policies and prompt students to form a broader management vision.

\section{The Coordination of Practice Base Construction}

The teacher leads the team to form more perfect management theory and suggestion for the development through the theory of concise management experience.

Therefore, the cultivation of MBA students need the cooperation of the three parties of the school/research institutes, enterprises and government. Based on the DNA double helix structure, colleges and universities cultivate the MBA students with full coverage of synergistic training in order to enhance the core competencies of the MBA students, just as shown in figure 2.

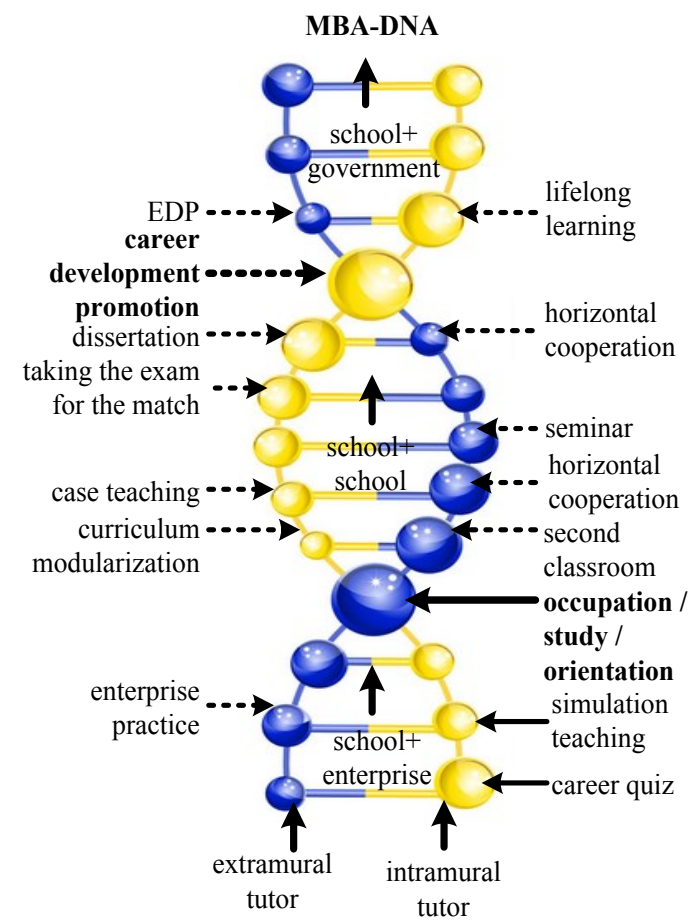

Figure.2 An integrated model of MBA talents' training based on double helix structure

\section{Conclusion}

The purpose of this paper is to construct a new and operational MBA talents' training mode, which is suitable for Chinese situation and can improve the quality of MBA education. Through the whole process and full coverage of synergistic cultivation, school should involve the MBA core competence into the DNA of management personnel and finally constructs MBA talents' training integration model based on the double helix structure, which can provide references to the China talents' cultivation with core competence.

\section{Acknowledgement}

This research was financially supported by the Foundation (NO.SDYY16110) as an important program, the Innovation Program of Shandong Graduates' Education.

\section{References}

[1]W. Yang, Synergistic innovation in graduates' education, J. Degree and Graduate Education. 6 
(2006)1-5.

[2]Z. F. Huang, L .L. Yi, Transformation of postgraduates' training mode from the perspective of collaborative innovation, J. Degree and Graduate Education4 (2014)7-10.

[3]D. Du, Q. H. Pang, Research on the "collaborative" postgraduates' training mode under the environment of collaborative innovation, J. Education and teaching research. 3(2014)86-90.

[4]Q. L. Wang, The comparison and Enlightenment of four foreign graduates' training mode, J. University Education Science. 1(2005)82-85.

[5]C.W. Sun, The innovation of graduates' cooperative education mode, J. Research on educational development.19 (2005)10-14.

[6]C.W. Sun, Breaking through the boundaries of the main body of college education-thinking about promoting the training mode of "collaborative" graduates, J. Chinese higher education evaluation.2 (2004)18-24.

[7]Y. Q. Xu, W. L. Wang, Reflection on the cultivation of innovative ability of graduate students, J. Chinese Higher Education.6 (2009)45-47.

[8]S. Zhang, Research on the problems and optimization of MBA education training mode in China, J. Talent resources development.1 (2016)184-185. 